\title{
Expression of Ciliary Tektins in Brain and Sensory Development
}

\author{
Jan Norrander, ${ }^{1}$ Magnus Larsson, ${ }^{2}$ Stefan Ståhl,,2 Christer Höög, ${ }^{3}$ and Richard Linck1 \\ ${ }^{1}$ Department of Cell Biology and Neuroanatomy, University of Minnesota, Minneapolis, Minnesota 55455, ${ }^{2}$ Department of \\ Biochemistry and Biotechnology, Kungliga Tekniska Högskolan, S-100 44, Stockholm, Sweden, and ${ }^{3}$ Department of Cell \\ and Molecular Biology, Center for Genomics Research, Karolinska Institutet, S-171 77, Stockholm, Sweden
}

Many types of neural tissues and sensory cells possess either motile or primary cilia. We report the first mammalian (murine testis) cDNA for tektin, a protein unique to cilia, flagella, and centrioles, which we have used to identify related proteins and genes in sensory tissues. Comparison with the sequence database reveals that tektins are a gene family, spanning evolution from Caenorhabditis elegans (in which they correlate with touch receptor cilia) and Drosophila melanogaster, to Mus musculus and Homo sapiens (in which they are found in brain, retina, melanocytes, and at least 13 other tissues). The peptide sequence RPNVELCRD, or a variant of it, is a prominent feature of tektins and is likely to form a functionally important protein domain. Using the cDNA as a probe, we determined the onset, relative levels, and locations of tektin expression in mouse for several adult tissues and embryonic stages by Northern blot analysis and in situ hybridization. Tektin expression is significant in adult brain and in the choroid plexus, the forming retina (primitive ependymal zone corresponding to early differentiating photoreceptor cells), and olfactory receptor neurons of stage embryonic day 14 embryos. There is a striking correlation of tektin expression with the known presence of either motile or primary cilia. The evolutionary conservation of tektins and their association with tubulin in cilia and centriole formation make them important and useful molecular targets for the study of neural development.

Key words: brain; C. elegans; centriole; chemo-/mechano-/ olfactory-/touch-/photo-receptor cells; choroid plexus; cilia; cytoskeleton; Drosophila; microtubule; olfactory epithelia; retina; RPNVELCRD-peptide; tekin; testis
Many types of neural tissues and sensory cells are highly ciliated (Peters et al., 1976; Stommel et al., 1980; Wheatley, 1982; Alberts et al., 1994). Motile cilia of ependymal cells generate the movement of CSF in the CNS of vertebrates, and motile cilia of statocyst hair cells form the basis for the detection of gravitational balance in invertebrates. Moreover, primary cilia (generally considered nonmotile) are widespread among neurons, sensory cells, and supporting cells in many animal phyla, providing structural support and possibly other functions. Thus, the functions of cilia in neural tissues and sensory cells deserve study yet only a few of their protein components have been characterized. The main structural component of cilia is the microtubule protein tubulin. The tubulin family includes at least 12 isoforms in vertebrates (cf. Joshi and Cleveland, 1990; Wilson and Borisy, 1997). In addition, tubulin may be posttranslationally modified by (de)acetylation, (de)tyrosination, glutamylation, glycylation, and phosphorylation (MacRae, 1997). The in vivo functions of these diverse tubulin isoforms and

Received June 29, 1998; revised Aug. 6, 1998; accepted Aug. 17, 1998.

This work was supported by USPHS Grant GM35648, National Science Foundation Grant DBI-9602237, March of Dimes Birth Defects Foundation Grant FY960741, Minnesota Medical Foundation Grant SMF-155-95, and University of Minnesota Graduate School Grant 17212 (to R.L.); the Swedish Natural Sciences Council and the Karolinska Institutet (to C.H.); and the Swedish Research Council for Engineering Sciences (to S.S.). We thank Eva Brundell, Aimee deCathelineau, Dr. Maureen Riedl, Li Yuan, and the lab of Dr. Martin Wessendorf for expert technical assistance, and Drs. Robert Elde, Paul Letourneau, and Steven McLoon for valuable discussions and critical readings of this manuscript.

General correspondence should be addressed to Dr. Richard Linck, Department of Cell Biology and Neuroanatomy, 4-144 Jackson Hall, University of Minnesota, 321 Church Street, Minneapolis, MN 55455.

E-mail addresses: norra001@maroon.tc.umn.edu (J.N.), magnus@biochem.kth.se (M.L.), stefans@biochem.kth.se (S.S.), christer.hoog@cmb.ki.se (C.H.), linck@ lenti.med.umn.edu (R.L.)

Dr. Norrander and Dr. Larsson contributed equally as first authors.

Copyright (C) 1998 Society for Neuroscience $0270-6474 / 98 / 188912-07 \$ 05.00 / 0$ modifications are not well understood, and to underscore this puzzle, simple organisms can assemble the complex microtubule arrays of cilia from a single $\alpha \beta$-tubulin dimer isoform (James et al., 1993). Ciliary movements are driven by the microtubule motor proteins dynein and kinesin (Gibbons, 1995; Beech et al., 1996; Porter, 1996; Bost-Usinger et al., 1997; Cole et al., 1998; Kreis and Vale, 1998; Pazour et al., 1998), which exist as multiple isoforms within a given cell and which are responsible for retrograde and anterograde axonal transport, respectively (Brady and Sperry, 1995; Kreis and Vale, 1998). Last are the tektin proteins (Linck, 1990), which are relatively specific to cilia (and related organelles). Tektins were originally characterized from sea urchins in which three tektins (A, $\sim 53 \mathrm{kDa}$; B, $\sim 51 \mathrm{kDa}$; , $\sim 47 \mathrm{kDa}$ ) form specialized filaments of the axonemal microtubules of cilia, flagella, and centrioles (Linck et al., 1985; Linck and Stephens, 1987; Steffen and Linck, 1988; Pirner and Linck, 1994; Nojima et al., 1995; Norrander et al., 1996). Tektins are thought to function in providing for the stability and structural complexity of axonemal microtubules.

We noted previously the similarity of sea urchin tektins to an expressed sequence tag (EST) clone from human brain tissue (Norrander et al., 1996). This observation prompted our interest in developing suitable probes that could be used to better investigate cilia in complex neural tissues. We report here the cloning of the first mammalian (murine) tektin cDNA. This sequence, together with recent data from GenBank, allows us to construct an evolutionary scheme for tektins and to correlate their presence with sensory cells. Then, experimentally, we used Northern blot analysis and in situ hybridization to identify and localize tektin expression in several adult and embryonic brain and sensory tissues of the mouse. 


\section{MATERIALS AND METHODS}

Cloning procedures. In a previous study of messenger RNAs expressed by mouse testis meiotic germ cells, a 294 nucleotide EST (MTEST638) was found to have significant sequence similarity to tektins from sea urchin embryonic cilia (Yuan et al., 1995). In this report, we used a partial cDNA clone (yran4) and standard procedures (Sambrook et al., 1989) to screen an adult mouse testis $\lambda$ ZapII library, from which we obtained a full-length cDNA, MT14. The DNA Sequencing and Synthesis Facility at Iowa State University (Ames, IA) performed automated sequencing.

Northern blot analysis. Multiple tissue Northern blots were obtained from Clontech (Palo Alto, CA). Inserts from the clones MT14 and yran4 were isolated on low-melt agarose gels and radiolabeled using Rediprime DNA Labeling System (Amersham, Arlington Heights, IL). Blots were prehybridized in $50 \%$ deionized formamide, $5 \times$ SSPE (see Sambrook et al., 1989), $10 \times$ Denhardt's solution, $100 \mu \mathrm{g} / \mathrm{ml}$ sheared salmon sperm DNA, and $2 \%$ SDS at $42^{\circ} \mathrm{C}$ for $3 \mathrm{hr}$. Hybridizations were performed in prehybridization solution plus $1 \times 10^{6} \mathrm{cpm} / \mathrm{ml}$ of probe at $42^{\circ} \mathrm{C}$ for $16 \mathrm{hr}$. Blots were washed as follows: $2 \times$ SSC (see Sambrook et al. 1989) and $0.05 \% \mathrm{SDS}$ at room temperature for $40 \mathrm{~min}$ with several changes of solution; and then $0.1 \times \mathrm{SSC}$ and $0.1 \% \mathrm{SDS}$ at $50^{\circ} \mathrm{C}$ for $40 \mathrm{~min}$ with one change of solution. Results were analyzed by autoradiography.

Preparation of probes for in situ hybridization. In situ probes were transcribed from linearized DNA using either the T7 promoter-T7 RNA polymerase (antisense RNA) or T3 promoter-T3 RNA polymerase (sense RNA). The transcription reaction contained $1 \mu \mathrm{g}$ of linearized template DNA, $80 \mathrm{~mm}$ HEPES, pH 7.5, $12 \mathrm{~mm} \mathrm{MgCl}_{2}, 10 \mathrm{~mm} \mathrm{NaCl}, 10$ mM DTT, $0.5 \mathrm{~mm}$ ATP, $0.5 \mathrm{~mm}$ CTP, $0.5 \mathrm{~mm}$ GTP, $0.184 \mathrm{~mm}$ UTP, 100 $\mu \mathrm{Ci}\left[\alpha-{ }^{35} \mathrm{~S}\right] \mathrm{UTP}$, and $20 \mathrm{U}$ of enzyme. Reactions were performed at $37^{\circ} \mathrm{C}$ for $1 \mathrm{hr}$. DNA was removed from the reaction using RNase-free DNaseI, and the probe was reduced to an average size of 100 nucleotides by controlled alkaline hydrolysis.

In situ hybridizations. Mouse embryo and adult testis sections, fixed in buffered paraformaldehyde and embedded in paraffin, were obtained from Novagen (Madison, W I). Slides were dewaxed with xylene and then rehydrated via a series of 5 min washes in $100,95,70,50$, and $30 \%$ ethanol. Slides were immersed in $0.2 \mathrm{~N} \mathrm{HCl}$ (to disrupt ribosomes and to make the mRNA more accessible for hybridization), deproteinated using Proteinase $\mathrm{K}$, and acetylated (to block free amino groups that can bind probe nonspecifically) by immersion in $0.1 \mathrm{M}$ triethanolamine- $\mathrm{HCl}, \mathrm{pH} 8$, followed by the addition of $0.25 \%$ acetic anhydride. Slides were equilibrated in $50 \%$ formamide, $0.6 \mathrm{M} \mathrm{NaCl}, 10 \mathrm{~mm}$ Tris- $\mathrm{HCl}, \mathrm{pH} 7.5,1 \mathrm{~mm}$ EDTA, $50 \mu \mathrm{g} / \mathrm{ml}$ heparin, and $10 \mathrm{~mm}$ DTT. Prehybridization was performed in equilibration solution with the addition of $10 \%$ polyethylene glycol 8000 and $1 \times$ Denhardt's solution at $50^{\circ} \mathrm{C}$ for $1 \mathrm{hr}$. Hybridizations were performed in prehybridization solution with the addition of 0.5 $\mathrm{mg} / \mathrm{ml}$ carrier DNA, $0.5 \mathrm{mg} / \mathrm{ml}$ tRNA, and $10^{7} \mathrm{cpm} / \mathrm{slide}$ of RNA probe. Twenty-five to $50 \mu$ l of hybridization solution was placed on each slide, and a siliconized coverslip was glued on top to prevent evaporation. Hybridization was performed at $50^{\circ} \mathrm{C}$ for at least $18 \mathrm{hr}$. Coverslips were removed by immersion in $2 \times \mathrm{SSC}$ at $50^{\circ} \mathrm{C}$. Slides were washed as follows: $2 \times \mathrm{SSC}$ and $10 \mathrm{~mm} \beta$-mercaptoethanol $(\beta \mathrm{ME})$ at $50^{\circ} \mathrm{C}$ for $30 \mathrm{~min} ; 2 \times$ $\mathrm{SSC}, 10 \mathrm{~mm} \beta \mathrm{ME}$, and $20 \mu \mathrm{g} / \mathrm{ml} \mathrm{RNase} \mathrm{A}$ at $37^{\circ} \mathrm{C}$ for $30 \mathrm{~min} ; 2 \times \mathrm{SSC}$, $50 \%$ formamide, and $10 \mathrm{mM} \beta \mathrm{ME}$ at $50^{\circ} \mathrm{C}$ for $30 \mathrm{~min} ; 0.2 \times \mathrm{SSC}, 14 \mathrm{~mm}$ $\beta \mathrm{ME}$, and $0.07 \%$ sodium pyrophosphate at $50^{\circ} \mathrm{C}$ for $60 \mathrm{~min}$ with one change of wash solution.

Autoradiography. Air-dried slides were initially used to expose Hyperfilm-Max (Amersham) to obtain low-resolution autoradiographs and to estimate the length of exposure time. Slides were dipped in Kodak NTB-2 Nuclear Tracking Emulsion (Eastman Kodak, Rochester, NY) and exposed at $4^{\circ} \mathrm{C}$ for $10-14 \mathrm{~d}$ ( 5 times longer than the film exposure time). Slides were developed in Kodak Dektol developer diluted 1:1 with water, rinsed, and fixed in Kodak Fixer.

Counterstaining and mounting. Fluorescent counterstaining was performed by incubation for $5 \mathrm{~min}$ in $0.001 \%$ Hoechst solution, followed by two 5 min washes with water. Slides were mounted with DPX (Fluka BioChemika, Ronkonkoma, NY).

Microscopy and image processing. Microscopy was performed using an Olympus BX-60 microscope (Olympus Optical, Tokyo, Japan). Images were taken with an Optronics CCD camera (Optronics Engineering, Goleta, CA) and captured using MetaMorph software (Universal Imaging Corporation, West Chester, PA). Fluorescent images were captured in gray scale for optimal resolution and colored to match the wavelength of Hoechst using Photoshop software (Adobe Systems, San Jose, CA). Stage-specific embryonic tissues were identified by reference to Kaufman (1992).
Sequence analysis. Sequence analysis was performed using the Wisconsin Sequence Analysis Package (Genetic Computer Group, Madison, WI) .

\section{RESULTS}

The murine testis cDNA MT14 contains 1408 nucleotides, encodes a full-length protein with a mass of $49,567 \mathrm{Da}$, and has a high degree of homology with tektins (Fig. 1). We first present the analysis of the sequence and then use MT14 as a probe for Northern blot and in situ hybridization studies.

The first comparison of tektin A, B, and C sequences revealed that, within sea urchins, tektins are a related set of proteins with a common predicted fibrous structure (Norrander et al., 1996). Our present study is the first to report a full-length mammalian cDNA, showing that tektins represent an extended family of proteins and genes with characteristic features. The predicted polypeptide sequence and structure of MT14 (Fig. 1) matches most closely with sea urchin tektin C in terms of identical (48\%) and conservatively substituted (60\%) residues; the homology between MT14 (mouse tektin C) and sea urchin tektin C is greater than the similarity between any pair of sea urchin tektins (A, B, or C). Like tektin C, the MT14 polypeptide chain is predicted to form extended rod homodimers with five major coiled-coil segments interrupted by short nonhelical linkers. Among the potentially important residues conserved between sea urchin and mouse (and human, see below) is the peptide RPNVELCRD, which is present in the last nonhelical linker of the polypeptide chain. In addition, there are four conserved cysteines, each occurring in nonhelical linkers and $\mathrm{C}$ terminus; the positions of the cysteines (in sea urchins) suggested that they function to stabilize (via disulfide bonds) interactions between tektins and/or between tektins and tubulin (Norrander et al., 1996)

A search of the GenBank data base revealed additional sequences that have a high degree of similarity and identity to tektins (Fig. 1), including genomic clones from Caenorhabditis elegans and Drosophila and numerous human ESTs from 15 different fetal, infant, and adult tissues, including brain, retina, melanocytes, testis, kidney, liver-spleen, B-lymphocytes, lung, pregnant uterus, multiple sclerosis lesions, and various tumors. Many of the clones shown contain cysteines in the conserved positions. One of the human ESTs from infant brain spans the region containing the exact RPNVELCRD peptide. From database searches, this peptide sequence appears only to be present in tektin-related proteins; it is therefore a signature sequence for tektins and is likely to form a functionally important domain. Nearly identical peptide signatures are found in Drosophila and $C$. elegans genomic clones, where instead they are RPNVENCRD and RPGIELCND, respectively. Besides this consensus domain, 17 other individual residues are invariantly conserved throughout the polypeptide chains of tektins selected from C. elegans, Drosophila, sea urchin, mouse, and human (Fig. 1).

The sequences of the human ESTs isolated from different tissues differ somewhat from MT14. Some of these differences could result from a more error-prone sequence within the ESTs. Alternatively, the divergent tektin-related ESTs could correspond to new tektins or to other members of the tektin gene family identified in sea urchins (e.g., to tektins A and B). ESTs with divergent but tektin-related sequences have been mapped to three different chromosome locations in the human genome. A retinal tektin EST (GenBank accession number G27368) maps to human chromosome 15, and two other tektin-related ESTs are located on chromosomes 11 (GenBank accession number AC000382) and 21 (GenBank accession number HSJ003295). 
1

50

100

MTVEEQVVEM LSNLDFESLE FEDVQCHICF QVNHEPVTFL TCKHSICAGC AGRWLSSCSV CPMCRTRVRE IHLNDDLKKK SLEFLKLHPE QELPEDIKWE

101150

200

QCCHETVFWS LQQRKRANES DAVFYGSQPV VPEHLSAEES NDFIETKRLE NIRIRLDVLT KQVAEQTPRV QQYYNVEKFN QLFYQNEISY RDEDQEWRMV

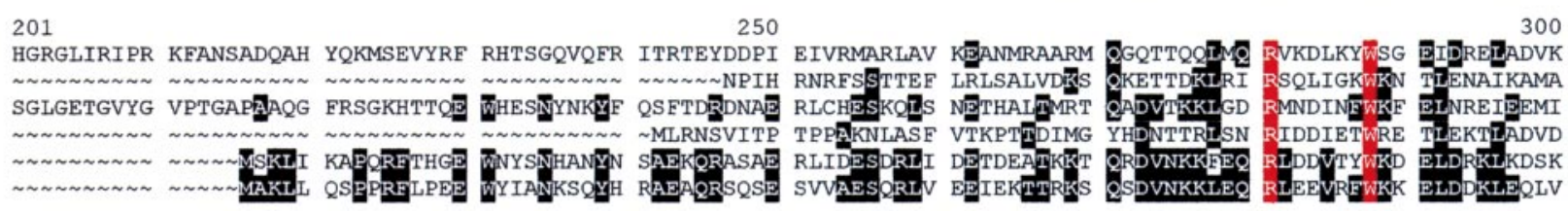

C. elegans Drosophila

Tektin A1

Tektin B1

Tektin $\mathrm{C1}$

Mouse MT14

Fetal Retina
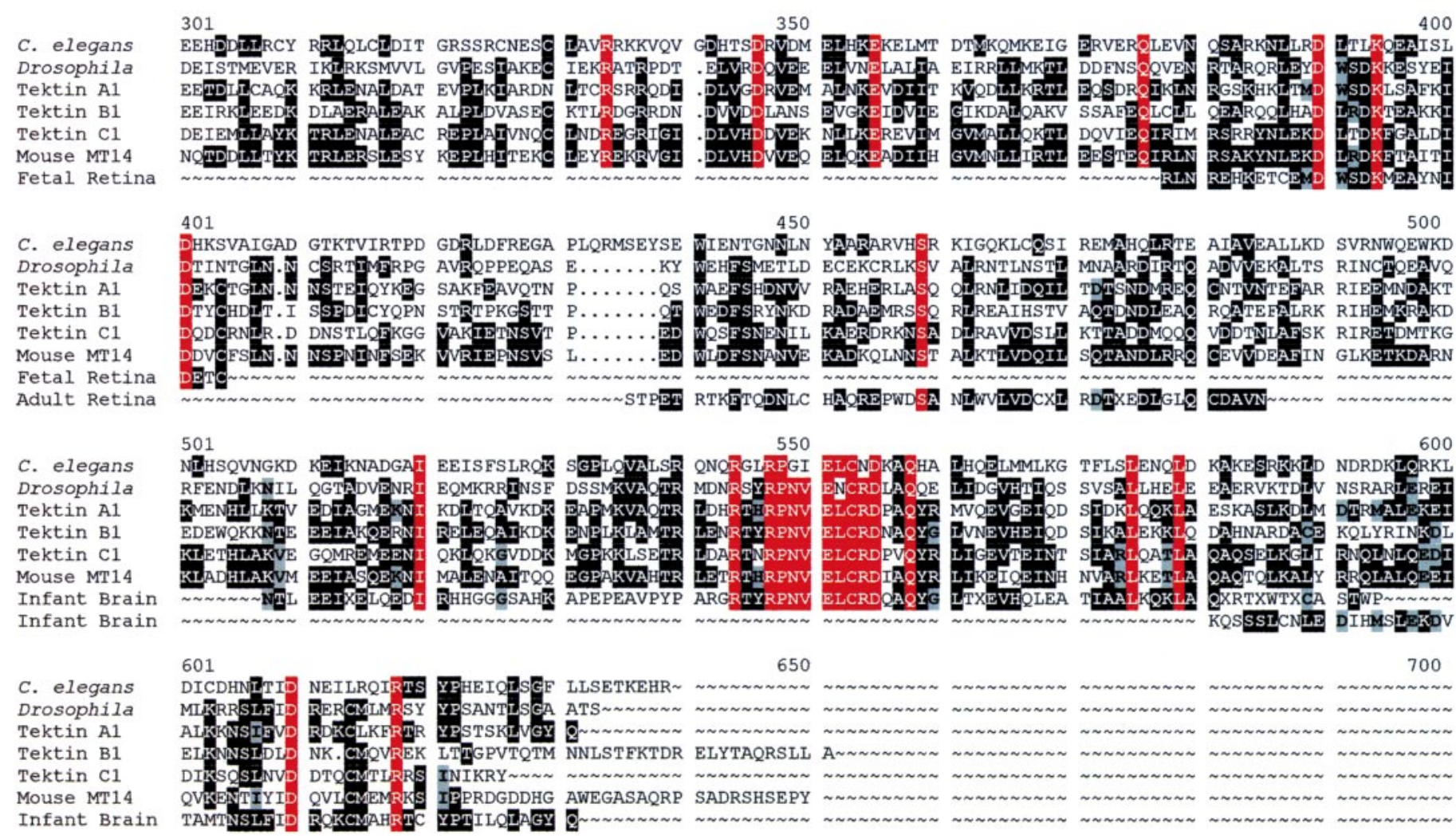

Figure 1. Comparison of tektin protein sequences from C. elegans, Drosophila, sea urchin, mouse and human. Black and gray blocks indicate residues that occur in one or more sea urchin tektins $(\mathrm{A} 1, \mathrm{~B} 1$, or $\mathrm{C} 1)$ and at least one mammalian sequence. Red blocks indicate regions of greatest homology (i.e., identities) among the tektins listed, including the peptide sequence RPNVELCRD, which is identically conserved in all sea urchin tektins, mouse MT14, and human infant brain; red regions are underestimates of complete identity, because differences in ESTs may represent sequencing errors. The peptide sequence RPNVELCRD shows some divergence in C. elegans (RPGIELCND) and Drosophila (RPNVENCRD). Also note the four highly conserved cysteines at positions 330,404, 553, and 614, referenced to C. elegans. Sequence data were obtained as follows: C. elegans, from $C$. elegans Genome Sequencing Project, GenBank accession number U53337 (locus CELR02E12); Drosophila, GenBank accession number AC002021; sea urchin tektin A1, GenBank accession number M97188 (Norrander et al., 1992); sea urchin tektin B1, GenBank accession number L21838 (Chen et al., 1993 ); sea urchin tektin C1, GenBank accession number U38523 (Norrander et al., 1996); mouse MT14, this report and GenBank accession number AF081947; human fetal retina, GenBank accession number AA487397; human adult retina, GenBank accession number H86604; and human infant brain, GenBank accession numbers T78294 and T10082.

These data support the notion that multiple tektin-related genes are also present in mammals.

Given the emerging sequences of tektins, and particularly those from human brain, retina and melanocytes, we were interested in examining the potentially wider presence and developmental importance of tektins in adult and embryonic vertebrate neural tissues by analyzing the expression of tektin transcripts in mouse. Blots of poly $\left(\mathrm{A}^{+}\right)$RNA isolated from eight different adult tissues (testis, lung, brain, heart, kidney, liver, skeletal muscle, and spleen) were probed with testis tektin cDNA MT14 (Fig. 2a). Transcripts hybridizing with MT14 were clearly detected in testis, lung, and brain. A band of $\sim 1550$ nucleotides was detected in lung and brain, and bands of $\sim 1550$ and $\sim 4000$ nucleotides were visible in testis; the relative abundance of transcripts in these tissues is evident (Fig. 2a). To examine the possible expression of tektins during embryonic development, blots containing poly $\left(\mathrm{A}^{+}\right)$RNA isolated from embryonic day 7 (E7), E11, E15, and E17 embryos were probed with mouse testis tektin cDNA clone yran4 (Fig. 2b). A band of $\sim 1550$ nucleotides is first detected in E11 embryos, and its level increases in E15 and E17 embryos.

To determine the location of tektin expression in mouse embryos, in situ hybridization experiments were performed using ${ }^{35}$ S-labeled MT14 antisense RNA, and as controls, labeled sense strand RNA for MT14 and antisense RNA for protamine were used (a protein only expressed in testis during spermatogenesis) 


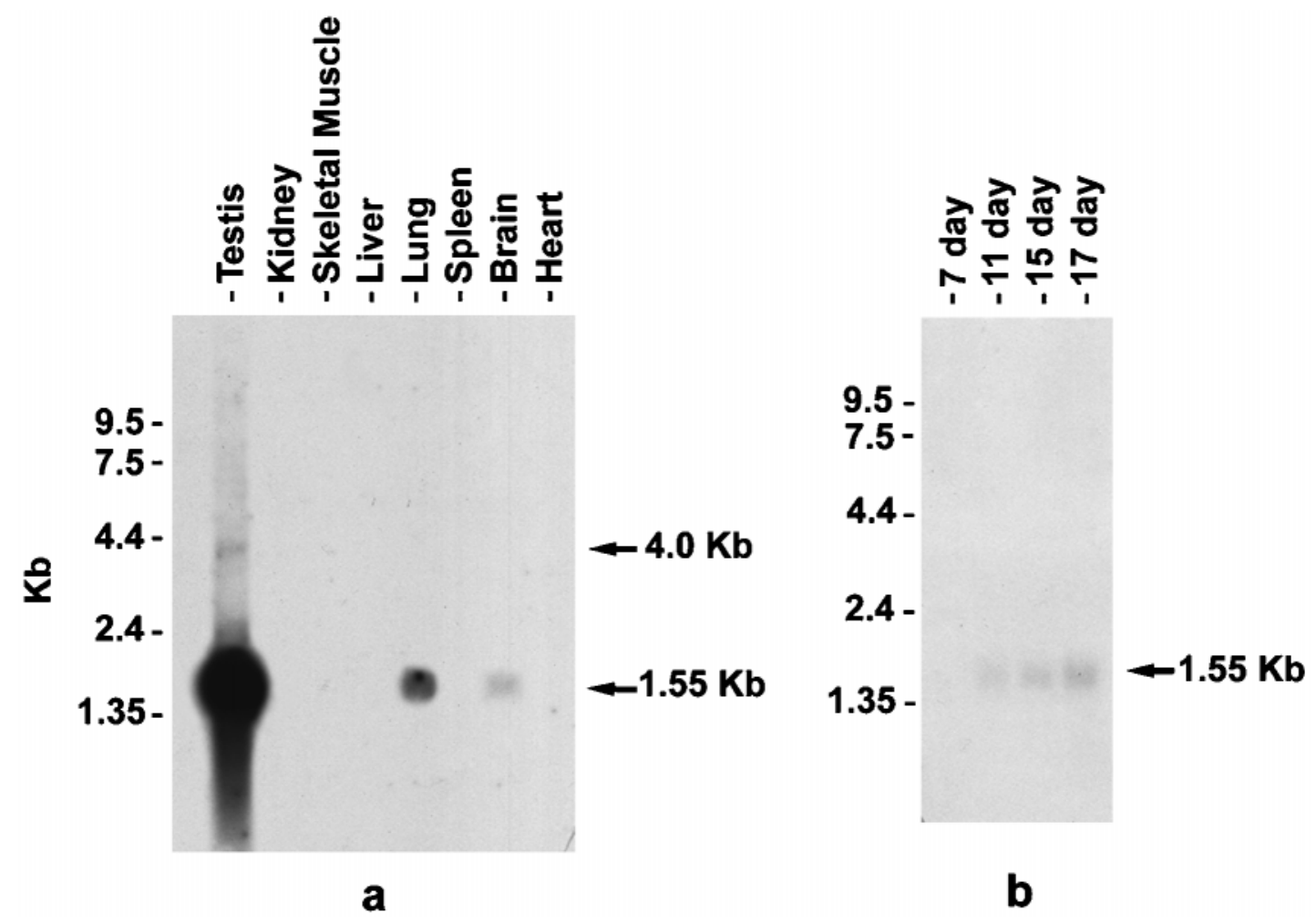

Figure 2. Northern blot analysis of mouse adult and embryonic tissues. $a$, Poly $\left(\mathrm{A}^{+}\right)$RNA from eight different adult tissues were probed with MT14. Bands of $\sim 1.5 \mathrm{~kb}$ are visible in testis, lung, and brain. In addition, a $4.0 \mathrm{~kb}$ band is present in testis. $b$, Poly $\left(\mathrm{A}^{+}\right)$RNA from four stages of mouse embryonic development were probed with yran 4 . A band of $\sim 1.5 \mathrm{~kb}$ is visible in increasing amounts starting at $11 \mathrm{~d}$. Lanes contained equal amounts of poly $\left(\mathrm{A}^{+}\right)$RNA $(2 \mu \mathrm{g})$ and relatively constant levels of the control $\beta$-actin transcript (data not shown).

(Zambrowicz et al., 1993; Wykes et al., 1995). We first examined embryonic stages at E8, E10, E12, E14, and E16, which revealed specific areas of labeling beginning at E12. To analyze more carefully the location(s) of tektin expression in the embryonic brain, we focussed on serial sagittal sections of E14 embryos. Specific labeling with antisense MT14 was localized to several neural tissues: (1) the choroid plexus of the lateral and fourth ventricles of the brain, (2) the developing retina, and (3) the olfactory epithelia (Fig. 3). No labeling was seen in embryos with negative controls, i.e., the sense strand RNA for MT14 or the antisense strand RNA for protamine (Fig. 3). In the retina, most of the labeling occurred in the primitive ependymal zone (cf. Sidman, 1961). In this region of the mouse retina at stage E14, cells committed to becoming photoreceptors are just beginning to proliferate (Turner et al., 1990; Altshuler et al., 1991). Although we cannot positively identify the labeled cells as early photoreceptors, we tentatively identify them as such, because photoreceptor cells will develop primary cilia (see below). Similarly, labeled cells of the olfactory epithelia are most likely developing olfactory receptor neurons, which will also elaborate long primary cilia.

\section{DISCUSSION}

The above results from the Northern blot and in situ hybridization analyses demonstrate that tektin C-related transcripts are differentially expressed in specific neural tissues during mouse development. We can best explain the tissue-specific expression of tektins by their association with ciliary microtubules.

Tektins form specialized filaments associated with the nine outer doublet microtubules of cilia and flagella; more specifically, tektin filaments are associated with a set of three chemically stable protofilaments of the A-microtubule wall, located near the inner junction with the B-tubule (Linck et al., 1985; Stephens et al., 1989; Linck, 1990; Nojima et al., 1995). Tektin filaments are composed of core protofilaments assembled from tektin A and B heterodimers; tektin $\mathrm{C}$ is thought to form homodimers assembled onto the periphery of these core protofilaments or to form a second separate tektin filament (Pirner and Linck, 1994). The association of tektins and tubulin may form the basis of the high degree of stability of doublet microtubules, and in addition, the location of tektin filaments in A-tubules and their periodic longitudinal spacings suggest that they may provide positional information for the attachment of inner dynein arms, radial spokes, nexin links, and/or the inner connection with the B-tubule (Stephens et al., 1989; Linck, 1990; Pirner and Linck, 1994; Nojima et al., 1995; Norrander et al., 1996); however, these postulated functions have yet to be demonstrated directly. As predicted from their structural roles, all three tektins, A, B, and C, are coordinately expressed during ciliogenesis (Norrander et al., 1995). In addition to the role of tektins in ciliary structure, immunoblot and immunofluorescence studies with species ranging from sea urchins and mollusks to humans strongly imply that tektin filaments extend from similar or identical filaments in basal bodies and centrioles (Steffen and Linck, 1988; Hinchcliffe and Linck, 1998; Stephens and Lemieux, 1998).

Based on the structural role of tektins, their expression in the organs and tissues observed here (Fig. 3) correlates with the presence of motile cilia and/or primary nonmotile cilia. The choroid plexus of the ventricles of the brain is lined with ciliated 

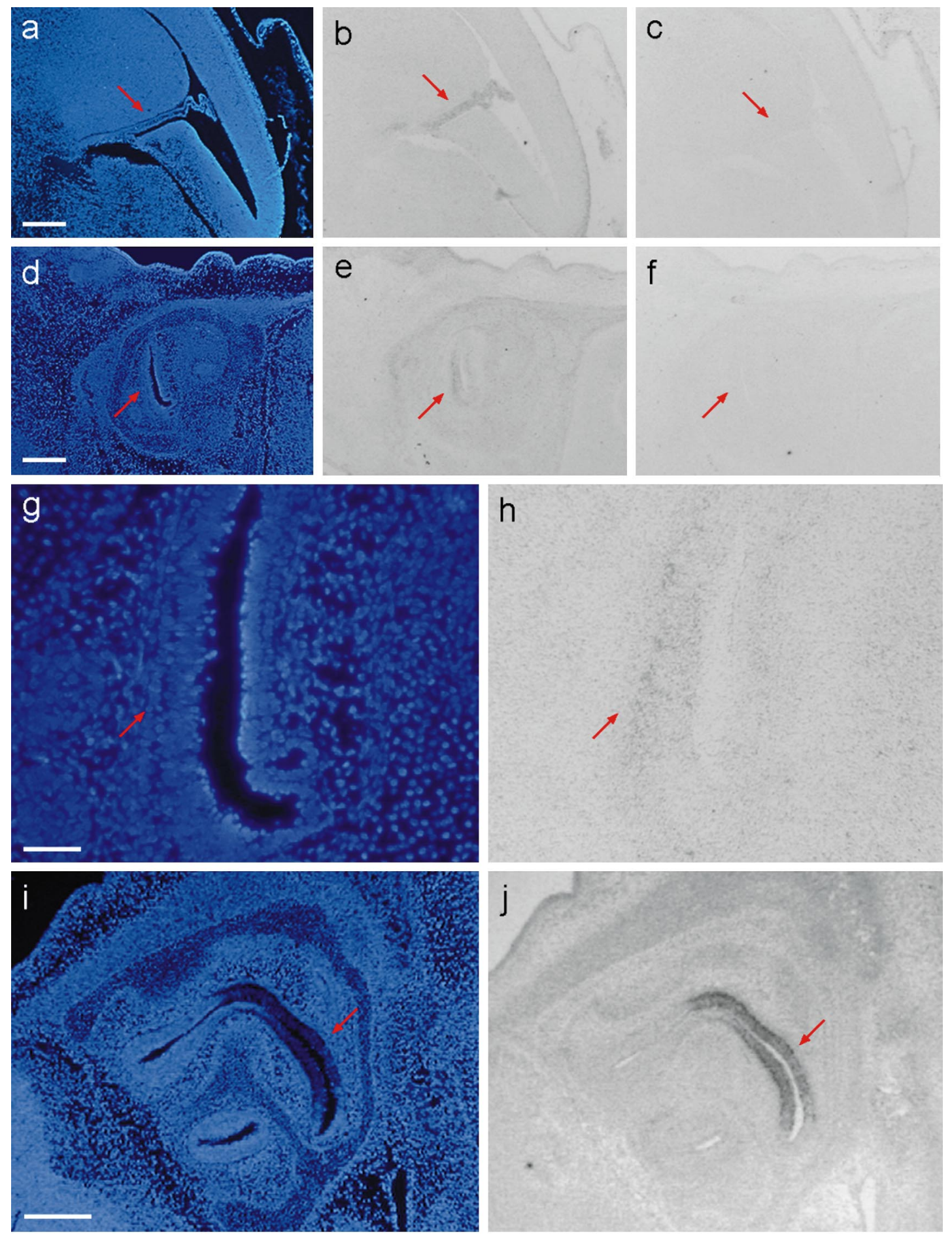

Figure 3. In situ hybridizations of E14 mouse embryos (sagittal sections, paraformaldehyde-fixed). $a-c$ represent serial sections of the lateral brain ventricle showing a Hoechst-stained fluorescence image $(a)$ and specific hybridization in the developing choroid plexus $(b, c$, arrows) with MT14 antisense RNA. $c$, No labeling is seen in tissues of an adjacent section probed with protamine antisense RNA. Scale bar (in $a$ ), $250 \mu$ m. $d-f$ represent serial sections of the eye showing a Hoechst-stained fluorescence image $(d)$, hybridization of MT14 antisense RNA in the developing retina $(e, f$, arrows), and absence of hybridization using MT14 sense RNA $(f)$. Scale bar (in $d$ ), $250 \mu \mathrm{m} . g$ (Hoechst-stained) and $h$ (hybridization with MT14 antisense RNA) show enlarged views of the retina. Scale bar (in $g$ ), $50 \mu \mathrm{m} . i$ and $j$ represent a section of olfactory epithelium (arrows) showing Hoechst-stained fluorescence image $(i)$ and specific hybridization with MT14 antisense RNA $(j)$. Protamine antisense RNA failed to label olfactory epithelium (data not shown). Scale bar (in $i$ ), $250 \mu \mathrm{m}$.

ependymal cells (Peters et al., 1976), which function in the surface transport of CSF to and through the central canal (also ciliated) of the spinal cord. Vertebrate retinal photoreceptors and olfactory receptor cells possess nonmotile primary cilia (Alberts et al., 1994). In invertebrates, e.g., C. elegans (Perkins et al., 1986) and Drosophila (Keil, 1997), primary cilia are associated with mechano-receptors (touch-receptors). Whereas the Drosophila clone shown in Figure 1 could represent a tektin gene for either 
mechanoreceptor cilia, sperm flagella, or centrioles, the C. elegans clone probably represents a tektin for touch receptors or centrioles, because $C$. elegans sperm do not contain microtubule-based flagella (Ward et al., 1986). Ciliary axonemes certainly act as rigid structural supports for photoreceptors (i.e., the connecting cilium between inner and outer rod segments) and for the cellular extensions of chemo-, osmo- and mechano-receptor membrane processes, and axonemes appear to provide the motile machinery for transport of molecular components to and from the receptor terminus (Beech et al., 1996; Cole et al., 1998). In addition, electrophysiological evidence from statocyst cilia suggests that ciliary axonemes play an active role in transmitting mechanical stimuli (Stommel et al., 1980; Stommel and Stephens, 1988), with dynein-mediated tension (but not motility per se) being required for membrane depolarization. The possible roles of tektins, as mentioned earlier, may be to form and stabilize the ninefold array of doublet and triplet microtubules. The potential role of tektins in generating the attachment sites for dynein arms and spokes may not be used in primary sensory cilia, which appear to lack these components; however, the frequency of occupancy of these sites is not known, and the presence of a small number of dynein arms might be required for sensory function.

A number of questions and experimental possibilities emerge from this work. First, it is important to determine the extent of the tektin gene family (e.g., in Mus musculus), to determine whether they are differentially expressed during development, and to determine the functions of the conserved sequence elements. In retina, expression of cilia-related genes might provide an earlier means of detecting the onset of photoreceptor development compared with opsin expression (Knight and Raymond, 1990; Watanabe and Raff, 1990; Altshuler et al., 1993; Neophytou et al., 1997). Ciliogenesis may also provide cues in the development and regeneration of olfactory receptor neurons from basal cells (Graziadei and Graziadei, 1993; Whitesides et al., 1998). Finally, tektins may be useful targets for analyzing the role of ciliary microtubules in signal transduction and diseases of sensory cells, as well as how primary cilia function in developing neurons in which the occurrence of primary cilia is widespread (Dahl, 1963; Wheatley, 1982, 1995).

\section{REFERENCES}

Alberts B, Bray D, Lewis J, Raff M, Roberts K, Watson JD (1994) Molecular biology of the cell. London: Garland.

Altshuler D, Turco JJL, Rush J, Cepko C (1993) Taurine promotes the differentiation of a vertebrate retinal cell type in vitro. Development 119:1317-1328.

Altshuler DM, Turner DL, Cepko CL (1991) Specification of cell type in the vertebrate retina. In: Development of the visual system (Lam DMK, Shatz CJ, eds), pp 37-58. Cambridge, MA: Massachusetts Institute of Technology.

Beech PL, Pagh-Roehl K, Noda Y, Hirokawa N, Burnside B, Rosenbaum JL (1996) Localization of kinesin superfamily proteins to the connecting cilium of fish photoreceptors. J Cell Sci 109:889-897.

Bost-Usinger L, Chen RJ, Hillman D, Burnside B (1997) Multiples kinesin family members expressed in teleost retina and RPE include a novel C-terminal kinesin. Exp Eye Res 64:781-794.

Brady ST, Sperry AO (1995) Biochemical and functional diversity of microtubule motors in the nervous system. Curr Opin Neurobiol 5:551-558.

Chen R, Perrone CA, Amos LA, Linck RW (1993) Tektin B1 from ciliary microtubules: primary structure as deduced from the cDNA sequence and comparison with tektin A1. J Cell Sci 106:909-918.

Cole DG, Diener DR, Himelblau AL, Beech PL, Fuster JC, Rosenbaum JL (1998) Chlamydomonas kinesin-II-dependent intraflagellar transport (IFT): IFT particles contain proteins required for ciliary assembly in Caenorhabditis elegans sensory neurons. J Cell Biol 141:993-1008.
Dahl HA (1963) Fine structure of cilia in rat cerebral cortex. Z Zellforsch Mikrosk Anat 60:369-386.

Gibbons IR (1995) Dynein family of motor proteins: present status and future directions. Cell Motil Cytoskeleton 32:136-144.

Graziadei PP, Graziadei AG (1983) Regeneration in the olfactory system of vertebrates. Am J Otolaryngol 4:228-233.

Hinchcliffe EH, Linck RW (1998) Two proteins isolated from sea urchin sperm flagella: structural components common to the stable microtubules of axonemes and centrioles. J Cell Sci 111:585-595.

James SW, Silflow CD, Stroom P, Lefebvre PA (1993) A mutation in the $\alpha 1$-tubulin gene of Chlamydomonas reinhardtii confers resistance to anti-microtubule herbicides. J Cell Sci 106:209-218.

Joshi HD, Cleveland DW (1990) Diversity among tubulin subunits: toward what functional end? Cell Motil Cytoskeleton 16:159-163.

Kaufman MH (1992) The atlas of mouse development. London: Academic.

Keil TA (1997) Functional morphology of insect mechanoreceptors. Microsc Res Tech 39:506-531.

Knight JK, Raymond PA (1990) Time course of opsin expression in developing rod photoreceptors. Development 110:1115-1120.

Kreis T, Vale R (1998) Guidebook to the cytoskeletal and motor proteins. Oxford: Oxford UP.

Linck RW (1990) Tektins and microtubules. Adv Cell Biol 3:35-63.

Linck RW, Stephens RE (1987) Biochemical characterization of tektin from sperm flagellar doublet microtubules. J Cell Biol 104:1069-1075.

Linck RW, Amos LA, Amos WB (1985) Localization of tektin filaments in microtubules of sea urchin sperm flagella by immuno-electron microscopy. J Cell Biol 10:126-135.

MacRae TH (1997) Tubulin post-translational modifications-enzymes and their mechanisms of action. Eur J Biochem 244:265-278.

Neophytou C, Vernallis AB, Smith A, Raff MC (1997) Muller-cellderived leukaemia inhibitory factor arrests rod photoreceptor differentiation at a postmitotic pre-rod stage of development. Development 124:2345-2354.

Nojima D, Linck RW, Egelman EH (1995) At least one of the protofilaments in flagellar microtubules is not composed of tubulin. Curr Biol 5:158-167.

Norrander JM, Amos LA, Linck RW (1992) Primary structure of tektin A1: comparison with intermediate filament proteins and a model for its association with tubulin. Proc Natl Acad Sci USA 89:8567-8571.

Norrander JM, Linck RW, Stephens RE (1995) Transcriptional control of tektin mRNA correlates with cilia development and length determination during sea urchin embryogenesis. Development 121:1615-1623.

Norrander JM, Perrone CA, Amos LA, Linck RW (1996) Structural comparison of tektins and evidence for their determination of complex spacings in flagellar microtubules. J Mol Biol 257:385-397.

Pazour GJ, Wilkerson CG, Witman GB (1998) A dynein light chain is essential for the retrograde particle movement of intraflagellar transport (IFT). J Cell Biol 141:979-992.

Perkins LA, Hedgecock EM, Thomson JN, Culotti JG (1986) Mutant sensory cilia in the nematode Caenorhabditis elegans. Dev Biol 117:456-587.

Peters A, Palay S, Webster H deF (1976) The fine structure of the nervous system: the neurons and supporting cells. London: Saunders.

Pirner MA, Linck RW (1994) Tektins are heterodimeric polymers in flagellar microtubules with axial periodicities matching the tubulin lattice. J Biol Chem 269:31800-31806.

Porter ME (1996) Axonemal dyneins: assembly, organization, and regulation. Curr Opin Cell Biol 8:10-17.

Sambrook J, Fritsch EF, Maniatis T (1989) Molecular cloning: a laboratory manual. Cold Spring Harbor, NY: Cold Spring Harbor Laboratory.

Sidman RL (1961) Histogenesis of mouse retina studied with thymidine$\mathrm{H}^{3}$. In: Structure of the eye (Smelser GK, ed), pp 487-506. London: Academic.

Steffen W, Linck RW (1988) Evidence for tektins in centrioles and axonemal doublet microtubules. Proc Natl Acad Sci USA 85:2643-2647.

Stephens RE, Lemieux NA (1998) Tektins as structural determinants in basal bodies. Cell Motil Cytoskeleton 40:379-392.

Stephens RE, Oleszko-Szuts S, Linck RW (1989) Retention of ciliary nine-fold structure after removal of microtubules. J Cell Sci 92:391-402.

Stommel EW, Stephens RE (1988) EGTA induces prolonged summed depolarizations in Mytilus gill coupled ciliated epithelial cells: implica- 
tions for the control of ciliary motility. Cell Motil Cytoskeleton 10:464-470.

Stommel EW, Stephens RE, Alkon DL (1980) Motile cilia transmit rather than directly transduce mechanical stimuli. J Cell Biol 87:652-662.

Turner DL, Snyder EY, Cepko CL (1990) Lineage-independent determination of cell type in the embryonic mouse retina. Neuron 4:833-845.

Ward S, Roberts TM, Strome S, Pavalko FM, Hogan E (1986) Monoclonal antibodies that recognize a polypeptide antigenic determinant shared by multiple Caenorhabditis elegans sperm-specific proteins. J Cell Biol 102:1778-1786.

Watanabe T, Raff M (1990) Rod photoreceptor development in vitro: intrinsic properties of proliferating neuroepithelial cells change as development proceeds in the rat retina. Neuron 2:461-467.

Wheatley DN (1982) The centriole: a central enigma of cell biology. Oxford: Elsevier Biomedical.
Wheatley DN (1995) Primary cilia in normal and pathological tissues. Pathobiology 63:222-238.

Whitesides J, Hall M, Anchan R, LaMantia AS (1998) Retinoid signaling distinguishes a subpopulation of olfactory receptor neurons in the developing and adult mouse. J Comp Neurol 394:445-461.

Wilson PG, Borisy GG (1997) Evolution of the multi-tubulin hypothesis. BioEssays 19:451-454.

Wykes SM, Nelson JE, Visscher DW, Djakiew D, Krawetz SA (1995) Coordinate expression of the PRM1, PRM2, and TNP2 multigene locus in human testis. DNA Cell Biol 14:155-161.

Yuan L, Liu J-G, Höög C (1995) Rapid cDNA sequencing in combination with RNA expression studies in mice identifies a large number of male germ cell-specific sequence tags. Biol Reprod 52:131-138.

Zambrowicz BP, Harendza CJ, Zimmermann JW, Brinster RL, Palmiter RD (1993) Analysis of the mouse protamine 1 promoter in transgenic mice. Proc Natl Acad Sci USA 90:5071-5075. 